\title{
Kinetics of substrate utilization and bacterial growth of crude oil degraded by Pseudomonas aeruginosa
}

\author{
Amirreza Talaiekhozani ${ }^{1,2}$, Nematollah Jafarzadeh ${ }^{3}$, Mohamad Ali Fulazzaky ${ }^{2,4^{*}}$, Mohammad Reza Talaie ${ }^{5,6}$ \\ and Masoud Beheshti
}

\begin{abstract}
Pollution associated with crude oil (CO) extraction degrades the quality of waters, threatens drinking water sources and may ham air quality. The systems biology approach aims at learning the kinetics of substrate utilization and bacterial growth for a biological process for which very limited knowledge is available. This study uses the Pseudomonas aeruginosa to degrade $\mathrm{CO}$ and determines the kinetic parameters of substrate utilization and bacterial growth modeled from a completely mixed batch reactor. The ability of Pseudomonas aeruginosa can remove $91 \%$ of the total petroleum hydrocarbons and $83 \%$ of the aromatic compounds from oily environment. The value $k$ of $9.31 \mathrm{~g}$ of substrate $\mathrm{g}^{-1}$ of microorganism $\mathrm{d}^{-1}$ could be far higher than the value $k$ obtained for petrochemical wastewater treatment and that for municipal wastewater treatment. The production of new cells of using CO as the sole carbon and energy source can exceed $2^{3}$ of the existing cells per day. The kinetic parameters are verified to contribute to improving the biological removal of $\mathrm{CO}$ from oily environment.
\end{abstract}

Keywords: Bacterial growth, Crude oil, Kinetic model, Pseudomonas aeruginosa, Substrate utilization

\section{Introduction}

The creation and evolution of technology for oil and gas industry can increase the capacity of oil and gas production $[1,2]$. However, the operation of oil and gas refineries may negatively affect the environmental quality, including air and water pollution [3]. The increase in oil and gas production can have benefits of the government's budget for the oil-producing countries but can also cause an increase in the release of pollutants into the environment. The chemicals in oil that are of most concern to humans are called such as total petroleum hydrocarbons (TPH) and aromatic compounds (AC) [4]. All of these chemicals may be released as water and air pollutants during the refining process. The petroleum refining processes of onshore/ offshore drilling and production having direct TPH and AC emission sources

\footnotetext{
* Correspondence: fulazzaky@gmail.com

${ }^{2}$ Centre for Environmental Sustainability and Water Security, Research Institute for Sustainable Environment, Universiti Teknologi Malaysia, 81310 UTM Skudai, Bahru, Johor, Malaysia

${ }^{4}$ Faculty of Civil Engineering, Universiti Teknologi Malaysia, Bahru, Johor, Malaysia

Full list of author information is available at the end of the article
}

may pollute the waters. In most reservoir traps, the formation water pushes the oil residues from the oil reservoirs resulting in a mixture of oil and water that might be collected during the oil extraction process, and then the water phase can be separated from the crude oil (CO) by special techniques. The water contains varying amounts of TPH and AC and needs to be treated by an appropriate method to ensure the treated water quality to match stringent standards. The oily wastewater, also known as the produced water, is brought to the surface from underground formations during the oil and gas production; it can be found in many oil-producing countries [5]. The potential of oilfield produced water to be a source of fresh water and the increasing environmental concerns to stringent legislations on the wastewater released into the environment have made oilfield produced water management a significant challenge of the oil and gas business [6]. Having observed that the dissolved toxic hydrocarbons like TPH and AC commonly have a higher impact on the environment [7], they do not break down into harmless carbon dioxide $\left(\mathrm{CO}_{2}\right)$ and water. Once the characteristics of the oily wastewater have 
been understood, the basic criteria for the selection of a definite separation technology can be proposed. The possibility of oily wastewater treated by physical, chemical and biological methods is an important process to ensure that the treatment system may be applied fairly. The use of locally isolated aerobic biosurfactantproducing bacteria has been researching more costefficient biological treatment methods, which are carried out with a minimum waste production and energy consumption [8-10]. The use of bacteria, yeast and fungi, which can grow using $\mathrm{CO}$ as the sole carbon source, has been reported with proper investigation of the hydrocarbons biodegradation cause [11-13].

Biological treatment is the most economic and ecofriendly process due to such a treatment offers least running cost, no requirement for hazardous chemicals and very low sludge production. The use of biosurfactantproducing bacteria is one way of removing many of the contaminants from many contaminated water, including $\mathrm{TPH}$ and $\mathrm{AC}$ from oily wastewater. Bioremediation is the promising technology for the treatment of oily wastewater [14-21]. Such a cost-effective technology of the mineralization may lead to complete breakdown of organic substances with the end products being $\mathrm{CO}_{2}$, $\mathrm{H}_{2} \mathrm{O}$ and nutrients [22]. The TPH in wastewater can be removed in 7 days of using the locally isolated oildegrading bacteria with higher than $80 \%$ efficiency [5]. Using a large-scale activated sludge to treat oily wastewater can remove $98 \%$ of the TPH [23]. The presence of nutrients, especially nitrogen and phosphorus, in wastewater effluents and their impacts on the biodegradation of TPH are of major concern for biological wastewater treatment process [24]. The presence of rhamnolipids produced by Pseudomonas aeruginosa can play an important role in initiating the biodegradation of $\mathrm{CO}$ [25]. The effects of fuel concentration (diesel and gasoline), nitrogen concentration and culture type on the biodegradation of synthetic effluent have been studied to show that the potential of biodegradability can remove $90 \%$ of the TPH over a process period of 49 days [21]. However, the systems biology approach to determine the kinetics of substrate utilization and bacterial growth still needs to be understood. The objectives of this study are: (1) to identify and select a suitable bacterial strain for degrading $\mathrm{CO}$ in a completely mixed batch reactor (CMBR) and (2) to verify the applicability of the kinetic models for the removal of CO from oily environment using the Pseudomonas aeruginosa as oil-degrading bacteria.

\section{Kinetic models}

The kinetic models could allow defining the optimal conditions for the degradation of organic matter with bacterial activity from an oily environment [26]. The rate of microbial growth in an aqueous environment would be related to the concentration of a limiting organic matter. Many mathematical models of different levels of complexity have been developed to describe the growth of microorganisms. In this study, the use of the Monod equation could be useful to compute the rate of substrate utilization related to the specific growth rate [27], such that:

$$
-r_{s u}=\frac{k \times X \times S_{0}}{K_{s}+S_{0}}=\frac{S_{0}-S}{\theta}
$$

where, $r_{\mathrm{su}}$ is the substrate utilization rate (in $\mathrm{mg} \mathrm{m}^{-3} \mathrm{~d}^{-1}$ ), $k$ is the maximum specific substrate utilization rate (in $g$ of substrate $\mathrm{g}^{-1}$ of microorganisms $\mathrm{d}^{-1}$ ), $S_{\mathrm{o}}$ is the concentration of the limiting substrate for growth (in $\mathrm{g} \mathrm{m}^{-3}$ ), $X$ is the microorganism concentration (in $\mathrm{g} \mathrm{m}^{-3}$ ), $K_{\mathrm{s}}$ is the half-velocity constant (in $\mathrm{g} \mathrm{m}^{-3}$ ), $\theta$ is the residence time (in d), and $S$ is the rest of the substrate concentration (in $\mathrm{g} \mathrm{m}^{-3}$ ).

Rearranging Eq. (1) in the form of linear equation yields:

$$
\frac{X \times \theta}{S_{0}-S}=\frac{K_{s}}{k} \times \frac{1}{S_{0}}+\frac{1}{k}
$$

It is clear that Eq. (2) is analogous to the linear equation [28, 29]: $Q=a \times P+b$, where $a$ is defined as slope and $b$ is interception of curve $\frac{X \times \theta}{S_{0}-S}$ versus $\frac{1}{S_{0}}, Q$ is $\frac{X \times \theta}{S_{0}-S}$ and $P$ is $\frac{1}{S_{0}}$.

The residence time of water and free-living bacteria could be the important factor in utilizing the limiting substrate for growth, relative to bacterial growth rate, for such an endogenous decay to occur. Thus, the inverse of the residence time can be defined as

$$
\frac{1}{\theta}=-\frac{Y \times r_{s u}}{X}-k_{d}
$$

where, $\theta$ is the residence time (in d), $Y$ is the synthesis yield coefficient (in $\mathrm{g}$ of biomass $\mathrm{g}^{-1}$ of substrate), $r_{\mathrm{su}}$ is the substrate utilization rate (in $\mathrm{mg} \mathrm{m}^{-3} \mathrm{~d}^{-1}$ ), $X$ is the microorganism concentration (in $\mathrm{g} \mathrm{m}^{-3}$ ), and $k_{\mathrm{d}}$ is the endogenous decay coefficient (in $g$ of microorganisms $\mathrm{g}^{-1}$ of biomass $\mathrm{d}^{-1}$ ).

When replacing $-r_{\text {su }}$ with $\frac{S_{0}-S}{\theta}$ in Eq. (3) yields a linear equation of:

$$
\frac{1}{\theta}=\frac{Y \times\left(S_{o}-S\right)}{\theta \times X}-k_{d}
$$

where, $\theta$ is the residence time (in d), $Y$ is the synthesis yield coefficient (in $\mathrm{g}$ of biomass $\mathrm{g}^{-1}$ of substrate), $S_{\mathrm{o}}$ is the concentration of the limiting substrate for growth (in $\mathrm{g} \mathrm{m}^{-3}$ ), $S$ is the rest of the substrate concentration (in $\mathrm{g} \mathrm{m}^{-3}$ ), $X$ is the microorganism 
concentration (in $\mathrm{g} \mathrm{m}^{-3}$ ), and $k_{\mathrm{d}}$ is the endogenous decay coefficient (in $\mathrm{g}$ of microorganisms $\mathrm{g}^{-1}$ of biomass $\mathrm{d}^{-1}$ ).

It is recognized that Eq. (4) is the linear equation: $J=Y \times I+k_{\mathrm{d}}$, where $Y$ is defined as slope and $k_{\mathrm{d}}$ is interception of curve $\frac{1}{\theta}$ versus $\frac{S_{0}-S}{X \times \theta}, J$ is $\frac{1}{\theta}$ and $I$ is $\frac{S_{0}-S}{X \times \theta}$.

The maximum specific growth rate of the bacteria is thus related to the maximum specific substrate utilization rate as follows [27]:

$$
\mu_{\max }=k \times Y
$$

where, $\mu_{\max }$ is the maximum specific bacterial growth rate (in $\mathrm{g}$ of new cells $\mathrm{g}^{-1}$ of cells $\mathrm{d}^{-1}$ ), $k$ is the maximum specific substrate utilization rate (in $g$ of substrate $g^{-1}$ of microorganisms $\mathrm{d}^{-1}$ ), $Y$ is the synthesis yield coefficient (in $g$ of biomass $g^{-1}$ of substrate).

\section{Materials and methods Sampling procedure}

It could be that the requirements for oil-degrading bacteria may rest largely on the petroleum-contaminated soils for several decades. Therefore, for the purpose of this work, one sample was taken from each location of oil-contaminated soils and effluents, i.e., (1) the soil around a gas station in Ahwaz city, (2) the soil around the Tehran oil refinery, (3) the outlet effluent of Tehran refinery wastewater treatment plant, and (4) the sanitary wastewater treatment plants of Tehran's refinery. To do an assay, a $250 \mathrm{~g}$ of soil sample dispensed into $2 \mathrm{~L}$ sterile glass bottle was taken from each oil-contaminated soil location at $5 \mathrm{~cm}$ depth and a $1 \mathrm{~L}$ of wastewater sample filled into $1 \mathrm{~L}$ sterile plastic bottle was taken from each oil-contaminated effluent location at $80 \mathrm{~cm}$ depth. All the samples should be maintained at a safe temperature of less than $4{ }^{\circ} \mathrm{C}$ in a cold box during transportation to the laboratory.

\section{Cultivation, screening and activation of the oil-degrading bacteria}

In this study, a $5 \mathrm{~g}$ of the soil sample was put into 500 $\mathrm{mL}$ of distilled water containing of $9 \mathrm{~g} \mathrm{~L}^{-1} \mathrm{NaCl}$ in an Erlenmeyer flask, mixed, and shaken at $160 \mathrm{rpm}$ for $30 \mathrm{~min}$ to have a suspension of bacteria in the liquid phase. Then $1 \mathrm{~mL}$ of the suspension bacteria was transferred to a $250 \mathrm{~mL}$ Erlenmeyer flask containing $100 \mathrm{~mL}$ of the nutrient solution (NS) and $1 \mathrm{~mL}$ of the $\mathrm{CO}$ as the sole carbon source and shaken at $160 \mathrm{rpm}$ and incubated at $30{ }^{\circ} \mathrm{C}$ for $30 \mathrm{~min}$. Notes that the NS consists of water containing a sufficient minerals i.e., $1 \mathrm{~g} \mathrm{~L}^{-1} \mathrm{NaNO}_{3}, 0.1 \mathrm{~g} \mathrm{~L}^{-1} \mathrm{MgSO}_{4} .7 \mathrm{H}_{2} \mathrm{O}, 0.01 \mathrm{~g} \mathrm{~L}^{-1}$ $\mathrm{CaCl}_{2}, 0.001 \mathrm{~g} \mathrm{~L}^{-1} \mathrm{FeSO}_{4}, 0.5 \mathrm{~g} \mathrm{~L}^{-1} \mathrm{~K}_{2} \mathrm{HPO}_{4}$ and $0.5 \mathrm{~g} \mathrm{~L}^{-1}$ $\mathrm{KH}_{2} \mathrm{PO}_{4}$ and has a $\mathrm{pH}$ of 7.2. For the cultivation of bacteria, $1 \mathrm{~mL}$ of the incubated sample was used to enrich microbes degrading oil in a $250 \mathrm{ml}$ Erlenmeyer flask containing $100 \mathrm{~mL} \mathrm{NS}$ and $1 \mathrm{~mL} \mathrm{CO}$ and shaken again at $160 \mathrm{rpm}$ and $30{ }^{\circ} \mathrm{C}$ for $72 \mathrm{~h}$. After that, $0.1 \mathrm{~mL}$ of the solution containing oil-degrading bacteria was selected streaked on a new NS agar plate and incubated at $30{ }^{\circ} \mathrm{C}$ for $48 \mathrm{~h}$, and this step was repeated until pure cultures were obtained. Note that the bacterial colonies with different characteristics of color and size might grow on the NS agar. The pure cultures obtained were maintained on the NS agar slants at $4{ }^{\circ} \mathrm{C}$ and must be transferred to the new NS agar slants regularly every four months. Then the nutrients broth (NB) was used as the medium for the activation of oildegrading bacteria. A large enough portion of the microbial growth from the slant culture was transferred to a $500-\mathrm{mL}$ Erlenmeyer flask containing $100 \mathrm{~mL}$ of $\mathrm{NB}$ and shaken at $160 \mathrm{rpm}$ and $30{ }^{\circ} \mathrm{C}$ and, after lasted for $24 \mathrm{~h}$, it was placed in an approved device and spun at $3000 \mathrm{rpm}$ in a centrifuge for $15 \mathrm{~min}$ and washed with sterile physiological saline solution to remove any contaminants. The bacteria were then suspended in physiological saline and could be ready for the future use.

\section{Measurement of crude oil degradation}

A small portion of oil-degrading bacteria was inoculated into a $500 \mathrm{~mL}$ Erlenmeyer flask containing $100 \mathrm{~mL}$ of NS. Then $1 \mathrm{~mL}$ of $\mathrm{CO}$ as the sole carbon source was added to the Erlenmeyer flask and was kept on the shaking incubator at $30{ }^{\circ} \mathrm{C}$ and $160 \mathrm{rpm}$ for 10 days, and then the amount of residual $\mathrm{CO}$ was measured after extraction of oil from the medium. Such experiment was repeated with different concentrations of $\mathrm{CO}$. For the purpose of the study of kinetics, five $250 \mathrm{~mL}$ Erlenmeyer flasks (numbered 1, 2, 3, 4 and 5) containing $100 \mathrm{~mL}$ NS were used to measure the kinetics of substrate utilization and bacterial growth. After that, $1 \mathrm{ml}$ of $\mathrm{CO}$ and $0.1 \mathrm{ml}$ of the bacterial solution were aseptically added to each Erlenmeyer flask and incubated at $30{ }^{\circ} \mathrm{C}$ with shaking at $160 \mathrm{rpm}$. The rests of $\mathrm{CO}$ concentration in the Erlenmeyer 1, 2, 3, 4 and 5 were measured over a four days period after 12, 24, 40, 48 and $92 \mathrm{~h}$ exposure period, respectively. The data obtained from this data collection technique were used for the calculation and comparison of the kinetic parameters of the substrate utilization and bacterial growth.

\section{Analytical methods}

A rapid spectrophotometric method based on a single optical density measurement was used to quantify biomass [30] and allowed the determination of biomass concentrations without the need for separation of the biomass from a solution. To measure the rest of $\mathrm{CO}$ in 
the solution, the $\mathrm{pH}$ was adjusted to 2 with $0.2 \mathrm{M} \mathrm{HCl}$. Then the residual $\mathrm{CO}$ was extracted with $25 \mathrm{~mL}$ of carbon tetrachloride $\left(\mathrm{CCl}_{4}\right)$ and then the sample was allowed to equilibrate for $15 \mathrm{~min}$. After that, $1 \mathrm{~mL}$ of the lower organic phase was transferred into a clean $100 \mathrm{~mL}$ volumetric flask and made up to $100 \mathrm{~mL}$ with $\mathrm{CCl}_{4}$ and then the sample was centrifuged at $3000 \mathrm{rpm}$ for $15 \mathrm{~min}$ in order to remove suspended particles and other substances that may interfere with the UV absorption measurement. The concentrations of TPH were determined using the UV spectrometer at $400 \mathrm{~nm}$ at which the maximum absorbance for a mixture of crude oil/ $\mathrm{CCl}_{4}$ occurs. The emulsifying activity of biosurfactants produced by each bacterial strain was measured by emulsification index $\left(E_{24}\right)$ as described by Cooper and Goldenberg [31]. A $6 \mathrm{~mL}$ of the culture supernatant was mixed with $6 \mathrm{~mL}$ of kerosene in a tube test. The mixture was vortexed at high speed for $2 \mathrm{~min}$ and lasted subsequently for $24 \mathrm{~h}$ before the measurement of $E_{24}$. The value of $E_{24}$ was determined from the ratio of the thickness of the emulsion layer to the total thickness of the mixture and then multiplied by $100 \%$ [32]. A gas chromatography (GC) of the Varian CP-3800 $\mathrm{GC}$ equipped with a flame ionization detector and a CP Sil 8 CB capillary column $(25 \mathrm{~m} \times 0.32 \mathrm{~mm}, 0.25 \mu \mathrm{m}$ film thickness) was used to determine the TPH and AC concentrations.

\section{Identification of bacterial isolates}

A number of physical and biochemical tests were performed for the identification of bacterial isolates with the help of standard methods [33], such that: (1) morphology observation by Olympus-CH40 microscope, (2) lactose test, (3) indole test, (4) urea utilization test, (5) motility test, (6) $\mathrm{H}_{2} \mathrm{~S}$ production test, (7) KCN growth test, (8) oxidase test, (9) gram test, (10) catalase test, (11) lysine dicarboxlaset test, (12) methyl red test, (13) Voges-Proskauer test, (14) citrate test, (15) pigment test, (16) dulcitol test, and (17) tartrate tests.

\section{Optimization of biological crude oil removal}

The optimum conditions of biological CO removal were investigated by Taguchi method; therefore, five important factors of temperature, $\mathrm{pH}$, initial $\mathrm{CO}$ concentration, hydraulic retention time (HRT), and nitrogen concentration were selected. Each factor was tested in three different conditions for which the temperatures of 20, 30 and $40{ }^{\circ} \mathrm{C}$ the $\mathrm{pH}$ of 6,7 and 8 , the initial $\mathrm{CO}$ concentrations of $0.05,3$ and $6 \%(\mathrm{v} / \mathrm{v})$, the HRTs of 5,10 and $15 \mathrm{~d}$, and the nitrogen concentrations of $0.2,1$ and $2 \mathrm{~g} / \mathrm{L}$ were set up for the experiments. Note that $\mathrm{NaNO}_{3}$ was used as a source of nitrogen. The results obtained were analyzed using a dedicated computer program of the Qualitek software.

\section{Results and discussion}

Ability of the bacterial strains to degrade crude oil hydrocarbons

In this work, fourteen strains of oil-degrading bacteria were isolated from hydrocarbon-polluted samples coming from the areas of contaminated soils and effluents in Iran. The bacterial strains that could use $\mathrm{CO}$ as the sole carbon and energy source were noted as bacterial strains A1, A2, A3, A4, A5, A6, A7, A8, A9, A10, A11, A12, A13 and A14. All these bacterial strains are compared with each other in terms of their ability to remove TPH and $\mathrm{AC}$ from oily environment. In spite of the bacterial strain A3 has an ability to remove approximately $85 \%$ of the TPH and approximately $86 \%$ of the $\mathrm{AC}$ as shown in Fig. 1, the figure shows that after 10 days a higher efficiency in removing TPH (91\%) could only be the bacterial strain A14. The GC analysis (see Fig. 2) conformed that the use of bacterial strain A14 can remove approximately $91 \%$ of the TPH. Therefore, the ability of bacterial strain A14 can remove TPH better than the strain A3. It seems that the ability of each bacterial strain to oxidize $\mathrm{CO}$ depends on direct cell-substrate contact and might be dependent on its ability to produce biosurfactants. The ability of bacterial strain A14 to remove AC would show slightly lower than that of bacterial strain A13. This may attribute to the cyclic structure of AC, which is more resistant to environmental degradation through chemical, biological and photolytic processes.

The growth of isolated bacteria in oily environment was investigated by inoculating the oil-degrading bacteria into a minimal culture medium (MCM) containing of $1 \%(\mathrm{v} / \mathrm{v}) \mathrm{CO}$ for 7 days. A $3 \mathrm{~mL}$ of bacterial strains was transferred from the MCM to a cuvette for the observation of cell growth identified by optimal optical density $\left(\mathrm{OD}_{600}\right)$, measured by a DR5000 Spectrophotometer at a wavelength of $600 \mathrm{~nm}$. The growth was categorized as low growth with $\mathrm{OD}_{600}$ in the range of 0.21-0.40, moderate growth in the range of $0.41-0.60$, high growth in the range of $0.61-0.80$, and

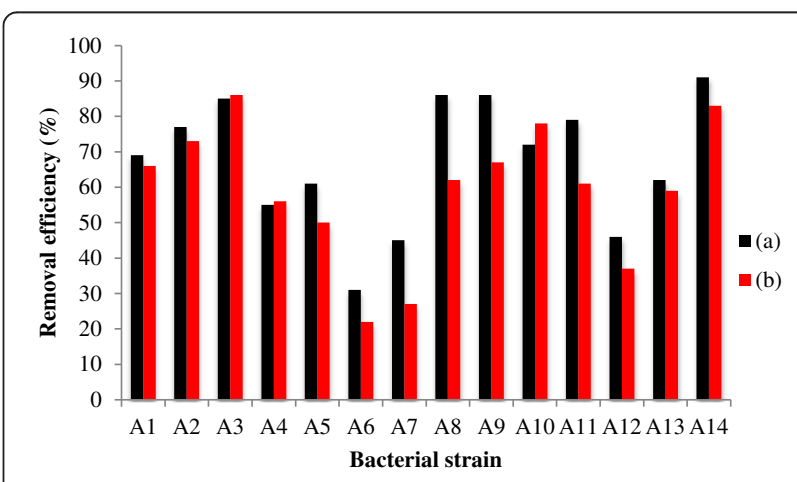

Fig. 1 Removal efficiency of crude oil degraded by different bacterial strains; (a) TPH and (b) AC 


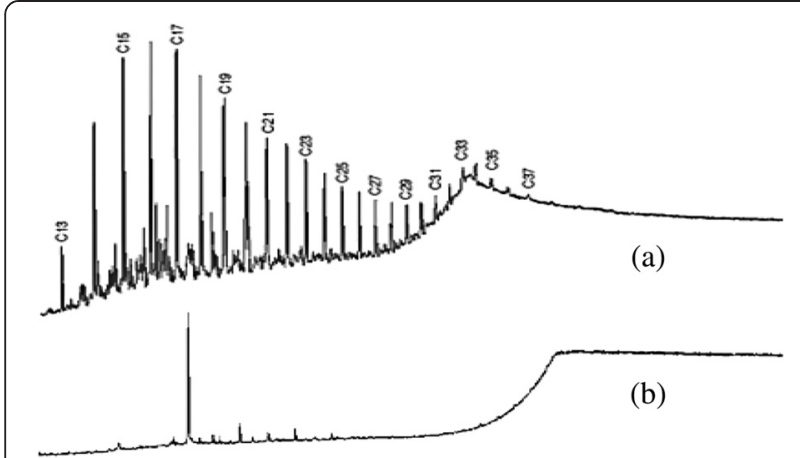

Fig 2 Results of GC analysis for the removal of TPH; (a) before degraded by Pseudomonas aeruginosa (b) after degraded by Pseudomonas aeruginosa excellent growth in the range of 0.81-1.00 [34]. The bacterial strain A14 has been identified as Pseudomonas aeruginosa [35]; the growth of such bacteria in oily environment can be categorized as high growth rate due to the $\mathrm{OD}_{600}$ value obtained of 0.661 should be in the range of 0.61-0.80. According the results of the optimization of biological CO removal, the optimum conditions of such a biological process are at a temperature of $30^{\circ} \mathrm{C}$, a pH of 7 , an initial CO concentration of $3 \%(\mathrm{v} / \mathrm{v})$, a HRT of $5 \mathrm{~d}$, and a nitrogen concentration of $1 \mathrm{~g} / \mathrm{L}$. The influence of each factor was ranked gradually from highest to lowest effect on the rate of $\mathrm{CO}$ degradation by Pseudomonas aeruginosa. The contributions of these factors are as follows: $27.36 \%$ for $\mathrm{pH}, 19.33 \%$ for nitrogen concentration, $10.31 \%$ for initial CO concentration and $9.69 \%$ for temperature. However, the influence of HRT on the CO removal by Pseudomonas aeruginosa would be nearly zero due to the experimental runs from 5 to $15 \mathrm{~d}$ have no effect on the increase in $\mathrm{CO}$ removal rate, suggesting that effective range of the HRT should be below than $5 \mathrm{~d}$.

\section{Emulsification}

Since only $0.02 \%$ of CO is water soluble, there is a need for emulsification, which is necessary for improving the bioavailability of petroleum hydrocarbons to microorganisms by increasing the interfacial area between the water and the insoluble hydrocarbons $[25,36]$. Biosurfactantproducing bacteria can consume $\mathrm{CO}$ as the sole carbon and energy source in various different forms including soluble $\mathrm{CO}$, very small $\mathrm{CO}$ droplets and large $\mathrm{CO}$ droplets. As demonstrated by numerous emulsification studies over the past few decades [37, 38], the presence of biosurfactant decreases the equilibrium droplet size of emulsions. The emulsifying activity of biosurfactants produced by fourteen bacterial strains was checked after being allowed to settle for $24 \mathrm{~h}$. Figure 3 shows that the highest values of $E_{24}$ is $36 \%$ for the bacterial strain A12, which has the

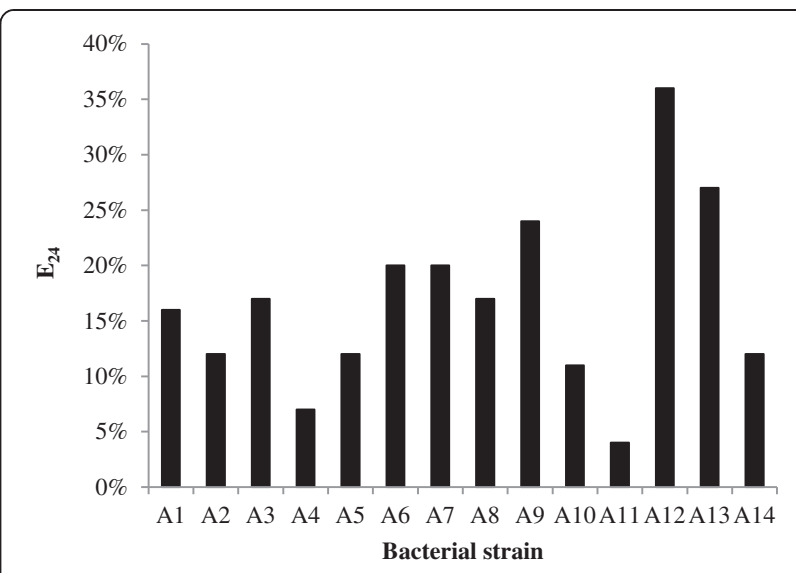

Fig. 3 The value of $E_{24}$ for different bacterial strains

ability to remove $46 \%$ of the TPH and $37 \%$ of the AC. However, the maximum values of TPH removal were 85 , 86, 86 and $91 \%$ achieved for the bacterial strains A3, A8, $A 9$ and A14, respectively, while the corresponding $E_{24}$ values were $17,17,24$ and $12 \%$, respectively. In spite of all the bacterial strains can produce biosurfactant during growth on the petroleum hydrocarbons [39], the biosurfactant did not affect the rate of $\mathrm{CO}$ biodegradation. The use of Pseudomonas aeruginosa was able of removing high concentrations of TPH (91\%) and AC (83\%) without any biosurfactant addition.

\section{Kinetics of substrate utilization}

Using Eq. (1) permits us to calculate $r_{\text {su }}$ and thus can be plotted it with different $S_{\mathrm{o}}$ used for bacterial growth. The relationship between $r_{\mathrm{su}}$ and $S_{\mathrm{o}}$ (Fig. 4) shows that at low concentration of $\mathrm{CO}$ there is a steep increase in

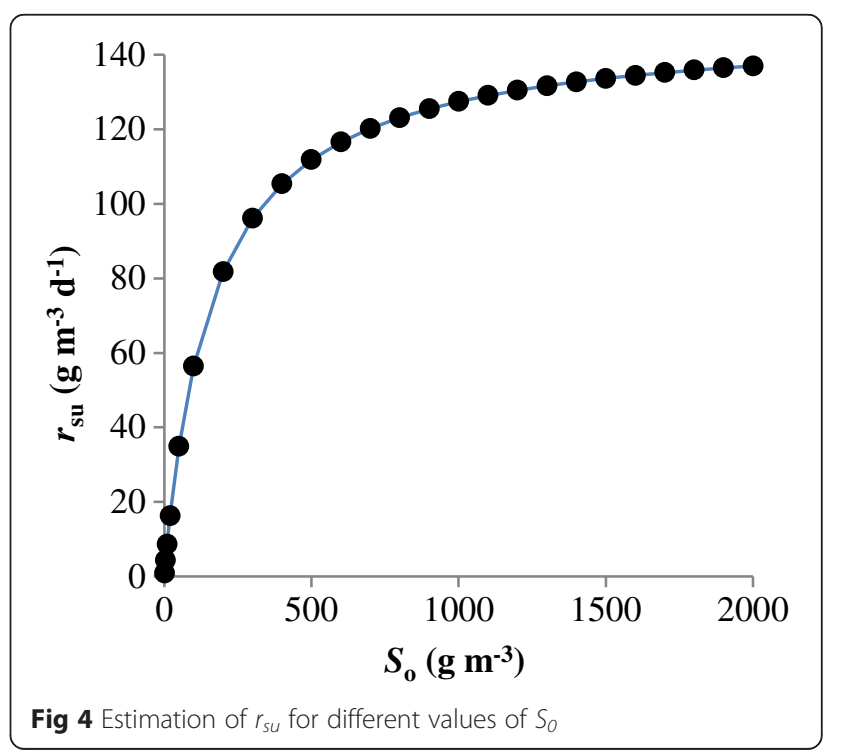


the rate of reaction with increasing $\mathrm{CO}$ concentration. However, at high concentration of $\mathrm{CO}$, one of the approaches has been to slow down the rate of growth on a readily metabolizable substrate like TPH by the addition of different $\mathrm{CO}$ concentrations to obtain ready release of the biosurfactants into the CMBR. Due to the low aqueous solubility of $\mathrm{CO}$, the ability of Pseudomonas aeruginosa to oxidize TPH depends on direct cellsubstrate contact [40].

A plot (Fig. 5) of $\frac{X \times \theta}{S_{0}-S}$ versus $\frac{1}{S_{0}}$ as modeled in Eq. (2) gives a straight line with $a$ equals 17.44 and $b$ equals 0.1074 . Therefore, the value of $k$ is equal to $9.31 \mathrm{~g}$ of substrate $\mathrm{g}^{-1}$ of microorganism $\mathrm{d}^{-1}$ and the value of $K_{\mathrm{s}}$ is equal to $162.4 \mathrm{~g} \mathrm{~m}^{-3}$ of substrate. Correlation for all the parameters in equation is good $\left(R^{2}=0.9811\right.$, see Fig. 5). According to Eq. (1), the low $K_{\mathrm{s}}$ for $\mathrm{CO}$ means that high rate of substrate utilization can be achieved at the low concentration, while the high $K_{\mathrm{s}}$ for $\mathrm{CO}$ means that much higher concentration of microorganisms would be needed to increase the utilization rate of $\mathrm{CO}$. An increase in the $k$ value would increase the rate of $\mathrm{CO}$ utilization. The Monod kinetic parameters of $k$ and $K_{\mathrm{s}}$ for petrochemical wastewater treatment have been reported in a previous study as $4.44 \mathrm{~g}$ of substrate $\mathrm{g}^{-1}$ of microorganism $\mathrm{d}^{-1}$ and $154.2 \mathrm{~g} \mathrm{~m}^{-3}$ of substrate, respectively [41]. However, the kinetics parameters of $k$ and $K_{\mathrm{s}}$ for the activated sludge process for the removal of organic matter from domestic wastewater could be in the range of 2-10 $\mathrm{g}$ of COD g $\mathrm{g}^{-1}$ of VSS d $\mathrm{d}^{-1}$ with a typical values of $5 \mathrm{~g}$ of COD g ${ }^{-1}$ of VSS $\mathrm{d}^{-1}$ and in the range of $10-60 \mathrm{~g} \mathrm{~m}^{-3}$ of COD with a typical value of $40 \mathrm{~g} \mathrm{~m}^{-3}$ of COD, respectively [27]. The use of Pseudomonas aeruginosa to degrade $\mathrm{CO}$ has been shown to result in increased substrate utilization rate, as its value $k$ of $9.31 \mathrm{~g}$ of substrate $\mathrm{g}^{-1}$ of microorganism $\mathrm{d}^{-1}$ could be far higher than the value $k$ obtained for petrochemical wastewater treatment (4.44 $\mathrm{g}$ of substrate $\mathrm{g}^{-1}$ of microorganism $\mathrm{d}^{-1}$ ) and that for municipal wastewater treatment ( $5 \mathrm{~g}$ of COD $\mathrm{g}^{-1}$ of VSS $\mathrm{d}^{-1}$ ). The kinetics of

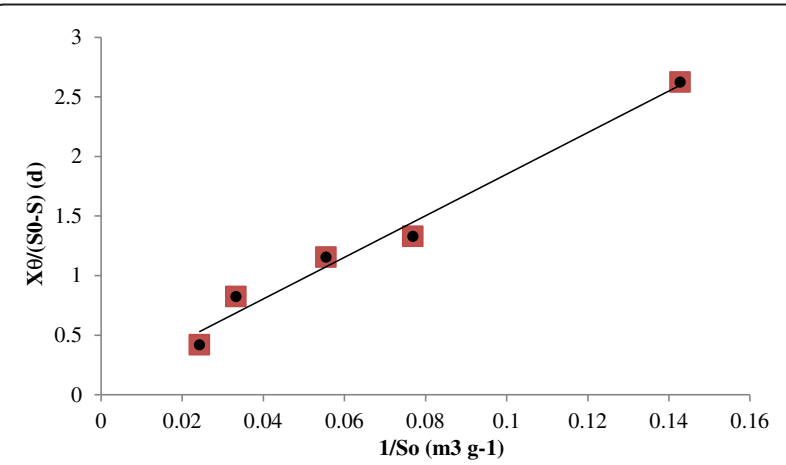

Fig 5 Graph of plotting $\frac{X \times \theta}{S_{0}-S}$ versus $\frac{1}{S_{0}}$ for the linear regression analysis substrate utilization would be the critically important factors that can be influenced by $\mathrm{CO}$ concentrations [42, 43]. With the value of $K_{\mathrm{s}}$ being around $162 \mathrm{~g} \mathrm{~m}^{-3}$ of substrate for oily wastewater treatment would work better if adding specific microorganisms at relatively high concentrations can accelerate start-up process by introducing Pseudomonas aeruginosa, which is capable of degrading $\mathrm{CO}$ in the oily environment.

\section{Microbial growth rate}

A plot (Fig. 6) of $\frac{1}{\theta}$ versus $\frac{S_{0}-S}{X \times \theta}$ as modeled in Eq. (4) gives a straight line with $Y$ equals $0.8896 \mathrm{~g}$ of biomass $\mathrm{g}^{-1}$ of substrate and $k_{\mathrm{d}}$ equals $0.1284 \mathrm{~g}$ of microorganisms $\mathrm{g}^{-1}$ of biomass $\mathrm{d}^{-1}$. Correlation for all the parameters in equation is very good $\left(R^{2}=0.9961\right.$, see Fig. 6). The microbial parameters of $Y$ and $k_{\mathrm{d}}$ for the activated sludge process for the removal of organic matter from domestic wastewater are in the range of 0.3-0.6 mg of VSS $\mathrm{g}^{-1}$ of COD with a typical value of $0.4 \mathrm{mg}$ of VSS $\mathrm{g}^{-1}$ of COD and in the range of 0.06 $0.15 \mathrm{~g}$ of $\mathrm{VSS}^{-1}$ of VSS $\mathrm{d}^{-1}$ with a typical value of $0.10 \mathrm{~g}$ of VSS $\mathrm{g}^{-1}$ of VSS $\mathrm{d}^{-1}$, respectively [27]. Using Eq. (5) permits us to calculate the value of $\mu_{\max }$, which is equal to $8.28 \mathrm{~g}$ of biomass (new cells) $\mathrm{g}^{-1}$ of microorganisms (existing cells) $\mathrm{d}^{-1}$. It seems that the production of new cells of using $\mathrm{CO}$ as the source of carbon and energy can exceed $2^{3}$ of the existing cells per day. The ability of Pseudomonas aeruginosa to degrade $\mathrm{CO}$ can be a frontrunner in creating a biological process for advanced oily wastewater treatment that can accelerate the development of sustainable biomass production in a CMBR, required the standardization of key technology and design parameters and processes.

\section{Conclusions}

This study used the Pseudomonas aeruginosa to remove CO from oily environment applied to a CMBR. The removal efficiencies of TPH and AC were verified as high

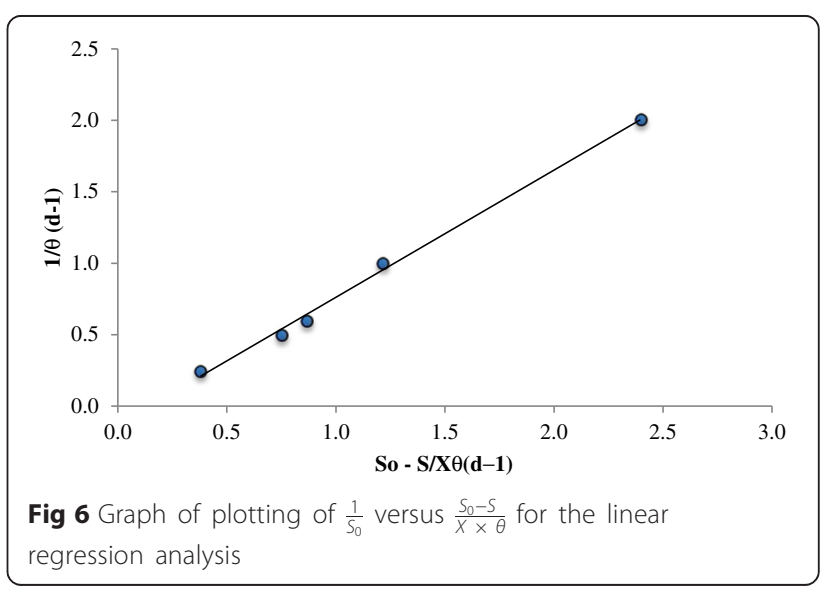


as 91 and $83 \%$, respectively, over a process period of 10 days. In spite of using the Pseudomonas aeruginosa to degrade $\mathrm{CO}$ can produce biosurfactant during growth on the petroleum hydrocarbons, such a bioproduct did not affect the $\mathrm{CO}$ degradation rate. The use of Pseudomonas aeruginosa to degrade $\mathrm{CO}$ has been shown to result in increased substrate utilization rate. The kinetics of substrate utilization and bacterial growth of using $\mathrm{CO}$ as the sole carbon and energy source were determined to contribute to improving the biological process for advanced oily wastewater treatment.

\section{Competing interests}

The authors declare that they have no competing interests.

\section{Authors' contribution}

AM carried out the experiments, together with the help of supervising $\mathrm{N} J$. NJ, MRT and MB participated in analysis of the experimental data and drafted the manuscipt. AM wrote the main manuscript text, together with the help of corresponding author MAF. MAF improved the manuscript to respond the reviewers' comments. MAF and AM contributed to the analysis of the results and prepared final figures. All authors read and approved the manuscript.

\section{Acknowledgment}

The authors gratefully acknowledge financial support from the Universiti Teknologi Malaysia for the Research University Grant: Vot. $07 \mathrm{H01}$ and also sincerely thank the Jami Institute of Technology, Isfahan, Iran for facilitating the flow of laboratory tests.

\section{Author details}

${ }^{1}$ Department of Civil and Environmental Engineering, Jami Institute of Technology, Isfahan, Iran. ${ }^{2}$ Centre for Environmental Sustainability and Water Security, Research Institute for Sustainable Environment, Universiti Teknologi Malaysia, 81310 UTM Skudai, Bahru, Johor, Malaysia. ${ }^{3}$ Department of Environmental Health, School of Health, Jondishapour University of Medical Science, Ahwaz, Iran. ${ }^{4}$ Faculty of Civil Engineering, Universiti Teknologi Malaysia, Bahru, Johor, Malaysia. ${ }^{5}$ Department of Chemical and Environmental Engineering, Faculty of Engineering, University of Nottingham Malaysia Campus, Kuala Lumpur, Malaysia. ${ }^{6}$ Department of Chemical Engineering, Isfahan University, Isfahan, Iran.

\section{Received: 19 July 2013 Accepted: 19 September 2015}

Published online: 24 September 2015

\section{References}

1. Fulazzaky M, Astuti DI, Fulazzaky MA. Laboratory simulation of microbial enhanced oil recovery using Geobacillus toebii R-32639 isolated from Handil Reservoir. RSC Adv. 2015;5:3908-16.

2. Kamarck ME. Building biomanufacturing capacity - the chapter and verse. Nat Biotechnol. 2006;24:503-5.

3. Mukherjee AK, Bordoloi NK. Bioremediation and reclamation of soil contaminated with petroleum oil hydrocarbons by exogenously seeded bacterial consortium: a pilot-scale study. Environ Sci Pollut Res. 2011;18:471-8.

4. Akhlag MS. Polycyclic aromatic hydrocarbons in crude oil-contaminated soil: A two-step method for the isolation and characterization of PAHs. Environ Sci Pollut Res. 1997;4:217-22.

5. Li Q, Kang C, Zhang C. Wastewater produced from an oilfield and continuous treatment with an oil-degrading bacterium. Process Biochem. 2005;40:873-7.

6. Igunnu ET, Chen GZ. Produced water treatment technologies. Int J Low-Carbon Technol doi:. 2012. doi:10.1093/ijlct/cts049.

7. Meijer DT, Madin C. Removal of dissolved and dispersed hydrocarbons from oil and gas produced water with MPPE technology to reduce toxicity and allow water reuse. APPEA J, 50 th Anniversary Issue. 2010. p. 1-12.

8. Affandi IE, Suratman NH, Abdullah S, Ahmad WA, Zakaria ZA. Degradation of oil and grease fom high-strength industrial effluents using locally isolated aerobic biosurfactant-producing bacteria. Int Biodeter Biodegr. 2014;95:33-40.

9. Aleksieva Z, Ivanova D, Godjevargova T, Atanasov B. Degradation of some phenol derivatives by Trichosporon cutaneum R57. Process Biochem. 2002;37:1215-9.

10. Mansur AA, Adetutu EM, Kadali KK, Morrison PD, Nurulita Y, Ball AS. Assessing the hydrocarbon degrading potential of indigenous bacteria isolated from crude oil tank bottom sludge and hydrocarbon-contaminated soil of Azzawiya oil refinery, Libya. Environ Sci Pollut Res. 2014;21:10725-35.

11. Kuo H-C, Juang D-F, Yang L, Kuo W-C, Wu Y-M. Phytoremediation of soil contaminated by heavy oil with plants colonized by mycorrhyzal fungi. Int J Environ Sci Technol. 2014;11:1661-8.

12. Margensin R, Schinner F. Bioremediation (natural attenuation and biostimulation) of diesel-oil-contaminated soil in an Alpine glacier skiing area. Appl Environ Microbial. 2001;67:3127-33.

13. Palittapongarnpim M, Pokethitiyook P, Upatham ES, Tangbanluekal L. Biodegradation of crude oil by soil microorganisms in the tropic. Biodegr. 1998:9:83-90.

14. Bielicka K, Kaczorek E, Olszanowski A, Voelkel A. Examination of biodegradation of hydrocarbons in emulsified systems. Pol J Environ Stud. 2002;11:11-6.

15. Gogoi BK, Dutta NN, Goswami P, Krishna Mohan TR. A case study of bioremediation of petroleum-hydrocarbon contaminated soil at a crude oil spill site. Adv Environ Res. 2003;7:767-82.

16. Grishchenkov VG, Townsend RT, Mcdonald TJ, Autenrieth RL, Bonner JS, Boronin AM. Degradation of petroleum hydrocarbons by facultative anaerobic bacteria under aerobic and anaerobic conditions. Process Biochem. 2000;35:889-96

17. Kaluarachchi JJ, Cvetkovic V, Berglund S. Stochastic analysis of oxygen- and nitrate-based biodegradation of hydrocarbons in aquifers. J Contam Hydrol. 2000:41:335-65.

18. Piedad Diaz M, Grigson SJ, Peppiatt CJ, Burgess JG. Isolation and characterization of novel hydrocarbon-degrading euryhaline consortia from crude oil and mangrove sediments. Mar Biotech. 2000;2:522-32.

19. Saleh-Lakha S, Miller M, Campbell RG, Schneider K, Elahimanesh P, Hart MM, et al. Microbial gene expression in soil: methods, applications and challenges. J Microbiol Methods. 2005;63:1-19.

20. Townsend GT, Prince RC, Suflita JM. Anaerobic biodegradation of alicyclic constituents of gasoline and natural gas condensate by bacteria from an anoxic aquifer. FEMS Microbiol Ecol. 2004;49:129-35.

21. Vieira PA, Vieira RB, de França FP, Cardoso VL. Biodegradation of effluent contaminated with diesel fuel and gasoline. J Hazard Mater. 2007;140:52-9.

22. Das N, Chandran P. Microbial degradation of petroleum hydrocarbon contaminants: An overview. Biotechnol Res Int. 2011;2011:941810.

23. Tellez GT, Nirmalakhandan N, Gardea-Torresdey JL. Performance evaluation of an active sludge system for removing petroleum hydrocarbons from oilfield produced water. Adv Environ Res. 2002;6:455-70.

24. Oh YS, Sim DS, Kim SJ. Effects of nutrients on crude oil biodegradation in the upper intertidal zone. Mar Pollut Bull. 2001;42:1367-72.

25. Wu ZG-I, Y-t QX-p, Meng Q. Biodegradation of crude oil by pseudomonas aeruginosa in the presence of rhamnolipids. J Zhejiang Univ Sci B. 2005;6:725-30

26. Hedhili K, Vauchel P, Dimitrov K, Kriaa K, Chataigné G, Hani K, et al. Mechanism and kinetics modeling of the enzymatic hydrolysis of a1-32 antibacterial peptide. Bioprocess Biosyst Eng. 2014;37:1315-23.

27. Tchobanoglous G, Burton FL, Stensel HD. Wastewater Engineering: Treatment and Reuse. 4th ed. Boston: McGraw-Hill; 2004.

28. Fulazzaky MA. Calculation of the release of total organic matter and total mineral using the hydrodynamic equations applied to palm oil mill effluent treatment by cascaded anaerobic ponds. Bioprocess Biosyst Eng. 2013;36:11-21.

29. Fulazzaky MA, Omar R. Removal of oil and grease contamination from stream water using the granular activated carbon block filter. Clean Technol Environ Policy. 2012;14:965-71.

30. Péquignot C, Larroche C, Gros JB. A spectrophotometric method for determination of bacterial biomass in the presence of a polymer. Biotechnol Tech. 1998;12:899-903.

31. Cooper DG, Goldenberg BG. Surface active agents from two Bacillus species. Appl Environ Microbiol. 1987;53:224-9.

32. Amiriyan A, Mazaheri Assadi M, Saggadian VA, Noohi A. Bioemulsan production by Iranian oil reservoirs microorganisms. Iranian J Environ Health Sci Eng. 2004;1:28-35. 
33. Barrow GL, Feltham RKA. Cowan and Steel's Manual for the Identification of Medical Bacteria. 3rd ed. Cambridge: Cambridge University Press; 1993.

34. Rahman KSM, Thahira-Rahman J, Lakshmanaperumalsamy P, Banat IM. Occurrence of crude oil degrading bacteria in gasoline and diesel station soils. J Basic Microbiol. 2002;42:286-93.

35. Talaie A, Beheshti M, Talaie MR. Screening and batch treatment of wastewater containing floating oil using oil-degrading bacteria. Desalin Water Treat. 2011;28:108-14.

36. Ebrahimipour G, Gilavand F, Karkhane M, Kavyanifard AA, Teymouri M, Marzban M. Bioemulsification activity assessment of an indigenous strain of halotolerant Planococcus and partial characterization of produced biosurfactants. Int J Environ Sci Technol. 2014;11:1379-86.

37. Chidambaram N, Burgess DJ. Effect of cationic surfactant on transport of surface-active and non-surface-active model drugs and emulsion stability in triphasic systems. AAPS Pharm Sci. 2000;2, E28.

38. McClements DJ, Weiss J. Bailey's Industrial Oil and Fat Products, Chapter 14: Lipid Emulsions. Sixthth ed. New Jersey: John Wiley \& Sons, Inc; 2005.

39. Ibacache-Quiroga C, Ojeda J, Espinoza-Vergara G, Olivero P, Cuellar M, Dinamarca MA. The hydrocarbon-degrading marine bacterium Cobetia sp. strain MM1IDA2H-1 produces a biosurfactant that interferes with quorum sensing of fish pathogens by signal hijacking. Microb Biotechnol. 2013;6:394-405.

40. Norman RS, Frontera-Suau R, Morris PJ. Variability in Pseudomonas aeruginosa lipopolysaccharide expression during crude oil degradation. Appl Environ Microbiol. 2002;68:5096-103.

41. Rahman MM, Al-Malack MH. Biochemical kinetics of cross flow membrane bioreactor processes in the treatment of refinery wastewater. Int J Environ Res. 2012:6:285-96.

42. Helbling DE, Hammes F, Egli T, Kohler H-PE. Kinetics and yields of pesticide biodegradation at low substrate concentrations and under conditions restricting assimilable organic carbon. Appl Environ Microbiol. 2014;80:1306-13.

43. Turkdogan-Aydinol Fl, Yetilmezsoy K, Comez S, Bayhan H. Performance evaluation and kinetic modeling of the start-up of a UASB reactor treating municipal wastewater at low temperature. Bioprocess Biosyst Eng. 2011;34:153-62.

\section{Submit your next manuscript to BioMed Central and take full advantage of:}

- Convenient online submission

- Thorough peer review

- No space constraints or color figure charges

- Immediate publication on acceptance

- Inclusion in PubMed, CAS, Scopus and Google Scholar

- Research which is freely available for redistribution 